\title{
Extra-Renal Lesion Caused by Dioctophyma renale Eggs in an Erratic Cycle in a Dog
}

\author{
Lesión Extra Renal Causada por los Huevos de Dioctophyma renale \\ en un Ciclo Errático en un Perro
}

\begin{abstract}
"Luciana da Silva Lemos; *Alessa Siqueira de Oliveira dos Santos; *Ana Bárbara Freitas Rodrigues; **:Maria Laudelina Vieira Seródio Goulart; "Luciano Grillo de Almeida \& *Leonardo Serafim da Silveira
\end{abstract}

LEMOS, L. S.; SANTOS, A. S. O.; RODRIGUES, A. B. F.; GOULART, M. L. V. S.; ALMEIDA, L. G. \& SILVEIRA, L. S. Extrarenal lesion caused by Dioctophyma renale eggs in an erratic cycle in a dog. Int. J. Morphol., 28(4):1031-1034, 2010.

SUMMARY: A dog with multiple infection by D. renale in the abdominal cavity presented granular peritonitis with giant cells phagocytizing $D$. renale eggs. Hepatic and phrenic serositis associated to numerous eggs of the parasite immersed in fibrinous process were observed. Lungs presented $D$. renale eggs in the parenchyma, mononucleated cell infiltrates, edema, hemorrhage, congestion, atelectasia, emphysema, and thromboembolism. D. renale eggs were detected inside the center-lobular veins, auricular cavities, and superficial venous bed of the heart. These findings characterized an atypical dissemination pathway of eggs in erratic cycle.

KEY WORDS: Egg; Dioctophyma renale; Erratic cycle; Extrarenal parasitism; Canine.

\section{INTRODUCTION}

Dioctophyma renale is a cosmopolitan parasite known as giant kidney worm. The parasite infests several mammal species, even man (Acha \& Szyfres, 2003; Fortes, 1997). D. renale is often described in dogs (Osborne et al., 1969; Amato et al., 1976; Kommers et al., 1999; Leite et al., 2005; Nakagawa et al., 2007). The parasite is commonly diagnosed in the right kidney and in the abdominal cavity (Osborne et al.; Amato et al.; Kommers et al.; Leite et al.) but it may parasitize both kidneys (Augusto Filho et al., 1999). Also, D. renale may be diagnosed only in the abdominal cavity. Other organs may also be affected, like the liver (Gargili et al., 2002), stomach and mesenterium (Miranda et al., 1992), causing perforations, hemorrhage and peritonitis (Osborne et al.; Monteiro et al., 2003).

The lesions caused by $D$. renale depend on the location in the body where the parasite is diagnosed (Kommers et al.). More specifically, in the kidney one or more worms (Amato et al.; Kano et al., 2003) cause the compressive destruction of the parenchyma (Leite et al.; Nakagawa et al.) and lead to the thickening of renal capsule due to the development of fibrosis (Leite et al.). The clinical expression of the parasitosis by $D$. renale is unspecific (Osborne et al.; Kommers et al.; Kano et al.; Monteiro et $a l$. ), or may even be absent (Osborne $e t a l$.). If only one kidney is infected, the renal function is preserved by the contralateral kidney (Kano et al.; Leite et al.; Monteiro et al.). Anemia (Kano et al.), hematuria, progressive weight loss (Kommers et al.; Nakagawa et al.) and abdominal distension may be signs associated to $D$. renale parasitosis (Kano et al.).

The parasite's preference for renal sites favors its cycle, which is long and complex. The cycle involves several hosts; eggs are eliminated through urinary ways of the infected host and then ingested by intermediate hosts, aquatic oligochaetes, which are ingested by paratenic hosts (fish and frogs). Definitive hosts and/or terminal hosts are infected by ingestion of contaminated oligochaetes or paratenic hosts (Fortes). Characteristically, D. renale eggs are large, elliptical, brown, thick-shelled, wrinkled, and are roughly between 60 and $80 \mathrm{~mm}$ in length and 39 and $46 \mathrm{~mm}$ in diameter (Osborne et al.). D. renale diagnosis is normally reached with casual necropsy findings, during surgical

\footnotetext{
* Laboratório de Sanidade Animal - Setor de Morfologia e Anatomia Patológica, Universidade Estadual do Norte Fluminense Darcy Ribeiro, Brasil.

*** Médica Veterinaria.
} 
procedures, in tests in urinary sediment and ascetic liquid (Kommers et al.; Leite et al.), and via radiographic and ultrasound investigation (Costa et al., 2004). As anatomopathological findings of $D$. renale in dogs are restricted to renal lesions, the aim of this study was to describe extra-renal lesions in tissue samples collected from a dog with peritonitis caused by multiple $D$. renale infestation.

\section{MATERIAL AND METHOD}

The study material consisted of tissue samples from a young, 7-kg mixed-breed dog (Canis familiaris) gone astray in the vicinities of Muriaé River, municipality of Itaperuna, state of Rio de Janeiro, Brazil. The animal presented cachexia, abdominal distension, anemia, hematuria.

The dog was treated with serum and antibiotics therapy and a blood transfusion, in a treatment period of 14 days, after which it died. A necropsy was conducted, after which the cardiorespiratory tract, mediastinic lymph nodes, liver and respective lymph nodes as well as part of the diaphragm were kept in formaldehyde $10 \%$ in totum. Viscera were inspected and sliced in several parts, including vascular coagula, and subsequently sectioned, mounted on slides and stained with hematoxylin/eosin (HE) for visualization in a light microscope. Egg morphometry was carried out using a digital morphometry software (Microimage Processing Software Dn-200M) with 20 eggs sectioned longitudinally.

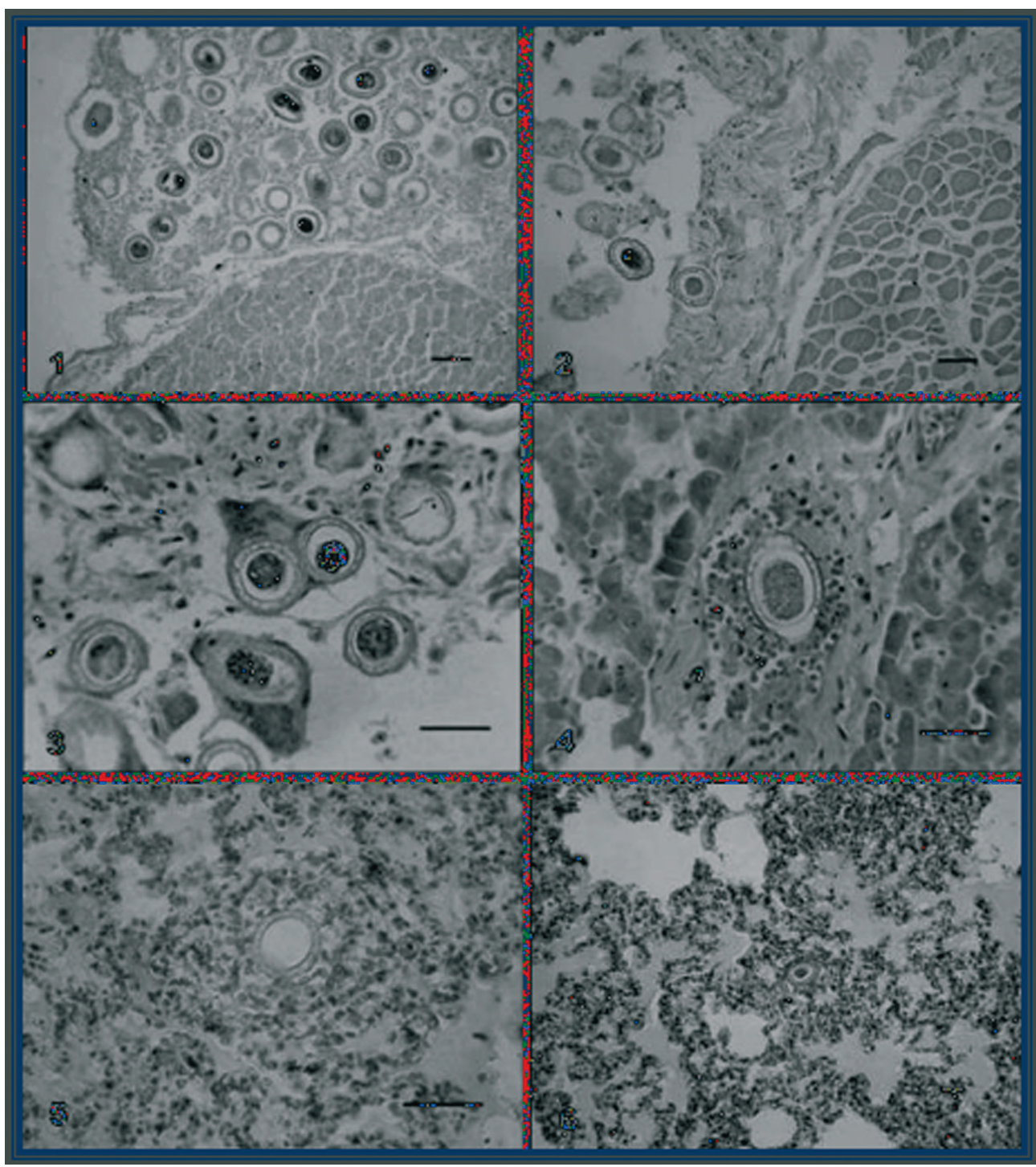

Fig. 1. Hepatic serositis. Fibrinous reaction imputed to innumerable $D$. renale eggs. $\mathrm{HE}$ staining. Objective 20x.

Fig. 2. Phrenic serositis. Fibrinous reaction imputed to innumerable $D$. renale eggs. $\mathrm{HE}$ staining, Objective 20x.

Fig. 3. Peritoneal granuloma by multinucleated foreign body giant cells phagocytizing $D$. renale eggs. HE staining. Objective 40x.

Fig. 4. Liver. D. renale egg in the center-lobular vein. HE staining. Objective 40x.

Fig. 5. Lung. D. renale egg immersed in mononucleated inflammatory cell infiltrates and alveolar emphysema. HE staining. Objective 40x.

Fig. 6. Lung. Alveolar emphysema, edema, atelectasie and $D$. renale egg. HE staining. Objective 10x. 


\section{RESULTS}

The incision in the abdominal cavity revealed a considerable amount of sanguinolent liquid, pale viscera, and signs of peritonitis, evinced by the accumulation of fibrin in the visceral and parietal peritoneum and by adhered areas in the mesenterium. Eleven adult nematodes identified as D. renale were found between intestinal loops. The right kidney was absent, indicating destruction by the worms. The inspection of the material by light microscopy confirmed the accumulation of fibrin in the liver and in the abdominal side of the diaphragm. Histopathological investigations revealed hepatic (Fig. 1) and phrenic serositis (Fig. 2). The eggs found were thick-shelled, irregularly shaped, chestnut brown in color and measured approximately $63 \times 40 \mathrm{~mm}$. In several microscopy fields eggs were involved in phagocytosis process represented by multinucleated foreign body giant cells (Fig. 3 ). The hepatic parenchyma sections revealed congestion, the presence of eggs inside center-lobular veins (Fig. 4), and thickening of the portal connective tissue.

The microscopy of lung samples revealed $D$. renale eggs were surrounded by mononucleated cell infiltrates (Fig. 5), destructuration of the histoarchitecture of lungs due to edema, hemorrhage, congestion, alveolar emphysema, thromboembolism, and $D$. renale eggs scattered in the parenchyma (Fig. 6), characterizing pneumonia. Eggs were observed in both auricular cavities and in the superficial venous bed of the heart. No eggs were found in the hepatic hilus or in mediastinic lymph nodes.

\section{DISCUSSION}

The anatomopathology of dogs infected with $D$. renale is commonly restricted to renal lesions (Amato et al.; Kommers et al.; Leite et al.; Nakagawa et al.), as the association with peritonitis and the effects on other organs are less frequently observed events (Amato et al.; Kano et al.; Monteiro et al.). Since the diagnosis of parasitosis is in most cases reached incidentally (Osborne et al.; Kommers et al.), the histopathological investigation of other organs as well as the physiopathology of peritonitis caused by $D$. renale has been the subject of limited research. This may be explained by the fact that the parasitosis by $D$. renale is symptomatically unspecific (Osborne et al.; Kommers et al.; Kano et al.; Monteiro et al.), and often occurs parenthetically to canine distemper, Hepatozoon sp, Ehrlichia sp (Porfirio et al., 2004), and leptospirosis (Costa et al.).

The peritonitis diagnosed in the present study was caused by worms and eggs, which led to irritation of the organ serous membrane and accumulation of fibrin, starting the inflammatory process in the peritoneum and the adherence of intestinal loops and mesenterium. The event may be explained by the fact that any noxious stimulus causing a lesion in the peritoneal mesothelium is enough to trigger an inflammatory response (Cotran et al., 1989), similar to that occurring in any other part of the organism and characterized by hyperemia, exudation, concentration of phagocytes, and local accumulation of fibrin. The inflammation in the peritoneum may be classified as primary, secondary or tertiary in relation to its origin being peritonitis (Wittmann et al., 1996; Zimmermann et al., 2006). In the present study, peritonitis by $D$. renale was classed as primary, as the process was of diffuse appearance in the peritoneal cavity, no hollow viscera was perforated, and no signs of bacterial presence were observed. Multiple infection, with females in their egg-laying stages and abundance of eggs in the peritoneal cavity characterized an inflammatory response that evolved into granular process represented by the amount of phagocytes that united to form foreign body giant cells in an attempt to isolate $D$. renale eggs. These eggs are inert, insoluble structures, and difficult to digeste - all of which are characteristics shared with Schistosoma mansoni eggs, also capable to induce granulomatous response (Atta et al., 1981; Lambertucci et al., 2005). Dogs are considered terminal hosts, uncommonly or accidentally infected (Acha \& Szyfres), since they often host one single parasite in the right kidney (Amato et al; Augusto Filho et al.; Kommers et al.; Monteiro et al.). In the natural cycle of $D$. renale, adult worms of both sexes are necessary in the kidneys to produce fertile eggs, whose dissemination pathway is the urinary tract (Osborne et al.).

In the animal studied in this case report, the erratic cycle was characterized by multiple infection in the abdominal cavity. Even though worms of both sexes and a large number of eggs were present, neither worm nor egg had the dissemination pathway clear to reach the environment. The records of $D$. renale in lung parenchyma and in the cardiac and hepatic vascular bed suggest that worms laid eggs in the circulatory system, an atypical dissemination pathway of eggs in their erratic cycle. The $D$. renale eggs are capable of inducing granular peritonitis and pneumonia, an observation so far unpublished in the literature reviewed. The findings of the present study emphasize the importance of more detailed anatomopathological investigations about the systemic involvement caused by the parasite.

\section{ACKNOWLEDGMENTS}

The collaboration of Helaíne Haddad Simões Machado. 
RESUMEN: Un perro con infección múltiple por D. renale en la cavidad abdominal presentó peritonitis granulomatosa con células gigantes fagocitando huevos de $D$. renale. Se pudo observar serositis hepática y frénica asociada a numerosos huevos del parásito inmersos en un proceso fibrinoso. Los pulmones presentaron huevos de $D$. renale en el parénquima, infiltrados de células mononucleares, edema, hemorragia, congestión, atelectasia, enfisema y tromboembolismo. Huevos de D. renale fueron detectados en el interior de la vena centro lobular, cavidades auriculares y lechos venosos superficiales del corazón. Estos hallazgos caracterizan una vía de diseminación atípica de los huevos en ciclo errático.

\section{PALABRAS CLAVE: Huevo; Dioctophima renale; Ciclo errático; Parasitismo extrarenal; Canino.}

\section{REFERENCES}

Acha, P. N. \& Szyfres, B. Zoonoses and communicable diseases commom to man and animais. Washington, OPAS, 2003.

Amato, J. F. R.; Grisi, L. \& Rosa, V. L. M. Reunião dos casos brasileiros de dioctofimose canina, com registro de mais alta intensidade de infecção por Dioctophyma renale (Goeze, 1782). Rev. Brasil. Biol, 36:117-22, 1976.

Atta, A. M.; Magalhães, L. A. \& Alcântara, G. P. Esquistossomose Mansônica. I. evolução do quadro patológico: análise parasitológica, hematológica e histopatológica. Rev. Saúde Pública, 15:72-92, 1981.

Augusto Filho, O.; Araújo, W. N.; Paes, A. C. \& Mamprim, M. J. Dioctofimíase canina bilateral com vários parasitas. Relato de caso. Seminário Brasileiro de Parasitologia Veterinária, XI. Salvador, Colégio Brasileiro de Parasitologia Veterinária, 1999.

Costa, P. R. S.; Neto, N. M. A.; Oliveira, D. M. C.; Vasconcelos, R. S. \& Menezes, F. M. Dioctofimose e leptospirose em um cão. Clínica Veterinária, 51:48-50, 2004.

Cotran, R. S.; Kumar, V. \& Robbins, S. L. Robbins Pathologic Basis of Disease. $4^{\text {th }}$ ed. Philadelphia, W. B. Saunders Company, 1989. pp.65-71.

Fortes, E. Parasitologia Veterinária. $3^{\text {rd }}$ ed. São Paulo, Ícone, 1997.

Gargili, A.; Firat, I.; Toparlak, M. \& Çetinkaya, H. First case report of Dioctophyme renale (Goeze, 1782) in a dog in Istanbul, Turkey. Turk. J. Vet. Anim. Sci., 26:1189-91, 2002.

Kano, F. S.; Shimada, M. T.; Suzuki, S. N.; Osaki, S. C.; Menarim, B. C.; Ruthes, F. R. V. \& Laidane Filho, M. A. Ocorrência de dioctofimose em dois cães no município de Guarapuava-PR. Ciências Agrárias, 24:177-80, 2003.

Kommers, D. G.; Ilha, M. R. S. \& Barros, C. S. L: Dioctofimose em cães: 16 casos. Ciência Rural, 29:517-22, 1999.

Lambertucci, J. R.; Moreira, R. F. \& Barbosa, A. J. A. Nódulo pulmonar solitário causado pelo Schistosoma mansoni em paciente com carcinoma medular da tireóide. Rev. Soc. Bras. Med. Trop., 38(6):536-7, 2005.
Leite, L. C.; Círio, S. M.; Diniz, J. M. F.; Luz, E.; Navarro-Silva, M. A.; Silva, A. W. C.; Leite, S .C.; Zadorosnei, A. C.; Musiat, K. C.; Veronesi, E. M. \& Pereira, C. C. Lesões anatomopatológicos presentes na infecção por Dioctophyma renale (Goeze, 1782) em cães domésticos (Canis Familiares, Linnaeus, 1758). Arch. Vet. Sci., 10:95-101, 2005.

Miranda, M. A.; Benigno, R. N. M.; Galvão, G. R. \& Oliveira, S. A. L. Dioctophyme renale (Goeze, 1782): localização ectópica e alta intensidade parasitária em Canis familiares do Pará - Brasil. Arq. Brás. Med. Vet. Zoot., 44:151-3, 1992.

Monteiro, S. G.; Sallis, E. S. \& Stainki, D. R. Infecção natural por trinta e quatro helmintos da espécie Dioctophyma renale (Goeze, 1782) em um cão. Rev. Fac. Zootec. Vet. Agro. Uruguaiana, 9:2932, 2003.

Nakagawa, T. L. D. R.; Bracarense, A. P. F. R. L.; Reis, A. C. F.; Yamamura, M. H. \& Headley, S. A. Giant kidney Word (Dioctophyma renale) infections in dogs from Northen Paraná, Brazil. Vet. Parasitol., 145:366-70, 2007.

Osborne, C. A.; Stevens, J. B. \& Hanlon, G. F. Dioctophyma renale in a dog. J. Am. Vet. Med. Assoc., 155:605-20, 1969.

Porfirio, L. C.; Carvalho, G. D.; Massariol, P. B.; Afonso, T. Z.; Machado, J. P. \& Masseno, A. P. B. Infecção concomitante por Dioctophyma renale, Hepatozoon sp., Ehrlichia sp. e cinomose em cão. Veterinária Ser., 1:16-22, 2004.

Wittmann, D. H.; Schein, M. \& Condon, R. E. Management of secondary peritonitis. Ann. Surg., 224:10-8, 1996.

Zimmermann, M.; Raiser, A. G.; Mazzanti, A.; Lopes, S. T. A. \& Salbego, F. Z. Peritonite em cães. Ciência Rural, 36:1655-63, 2006.

Correspondence to:

Luciana da Silva Lemos

Laboratório de Sanidade Animal

Setor de Morfologia e Anatomia Patológica

Universidade Estadual do Norte Fluminense Darcy Ribeiro (UENF)

Av. Alberto Lamego 2000

Horto, Campos dos Goytacazes

BRASIL

Email: luciana@uenf.br

Received: 18-05-2010

Accepted: 29-08-2010 